DOI: [10.9774/GLEAF.8757.2016.ju.00004]

\title{
Land of the Unexpected
}

\author{
Natural Resource Conflict and Peace Building \\ in Papua New Guinea*
}

Kylie McKenna

Australian National University, Australia

Natural resource conflict

Peace building

Papua New Guinea

Business and peace

Corporate social responsibility

Extractives industry
Papua New Guinea (PNG) has long been a site of analysis for exploring the links between natural resources and conflict, having been cited as an example in prominent studies of the "natural resource curse" and used as a source of learning in international debates on corporate social responsibility (CSR). Over the past decade, this scholarship has expanded to encompass conflict analysis and peace building. This paper considers four themes identified in the contemporary literature, each with reference to examples drawn from PNG: 1) the costs of conflict on business and the power of local communities; 2) tensions between the state as regulator and the state as shareholder; 3) the unsatisfactory performance of compensation packages and CSR projects; and 4) an emphasis on the economic dimensions of the natural resource curse in the search for new frameworks. Through a discussion of these themes, the paper calls for the development of natural resource conflict mitigation strategies that are based on a deeper understanding of the strengths and weaknesses of existing CSR measures.
Dr Kylie McKenna is a Visiting Fellow at the Development Policy Centre, The Australian National University. Dr McKenna's research explores the dynamic nexus of business, conflict, violence and peace building in Papua New Guinea and West Papua. She is the author of Corporate Social Responsibility and Natural Resource Conflict (2016, Routledge).
Crawford School of Public Policy/ Development Policy Centre, The Australian National University, 7 Liversidge St, Lennox Crossing, Australian National University, ACT, 2601, Australia

kylie.mckenna@anu.edu.au

* This paper is dedicated to the square pegs. 
APUA NEW GUINEA (PNG) HAS long been a site of analysis for exploring the links between natural resources and conflict (see Banks, 2008 for an overview). Natural resources have been central to the history of this young nation, whose independence from Australia in I975 was in part funded by mineral revenues generated from the massive Panguna mine in Bougainville. ${ }^{1}$ This mine was forced to close down in I989 when it became linked to the "most damaging conflict ever to occur amongst Pacific Islanders, causing thousands of deaths" (Regan, 20I2, p. II9). This conflict stemmed from complaints relating to mine revenue distribution and preferential employment by two main groups of Bougainvilleans: I) customary landowners of land leased to Bougainville Copper Limited (BCL); and 2) young Bougainvillean mine workers (Regan, 20I0, pp. I7-I8). Bougainville therefore, is one of PNG's "earliest and most well-known exemplars of the need for CSR in the extractive industry sector" (Gilberthorpe and Banks, 20I2, p. I86).

PNG reflects the trademarks of natural resource conflict globally: a country rich in natural resources (forestry, agriculture, fisheries and minerals) ${ }^{2}$ yet continues to lag behind on human development outcomes (UNDP, 20I2); characterized as a "weak state" noted for its "resilient largely self-regulating villagebased societies, and police forces with limited reach, resources, and popular legitimacy" (Dinnen et al., 2006, p. 87); widespread corruption (Macintyre et al., 2008, p. IOI); and environmental damage and associated campaigns directed at extractive companies (Kirsch, 2007; Macintyre and Foale, 2002).

PNG has also been a source of learning in international debates on CSR (Gilberthorpe and Banks, 20I2) and is cited in the work of influential "natural resource curse" authors including Collier (2000) and Ross (2003). This scholarship exposes the contradiction that instead of prosperity and peace, natural resource wealth can also result in poverty and conflict. Key themes identified in the literature are that resource abundant developing states tend to be associated with poor economic growth, poverty, corruption, state weakness, authoritarianism and repression, all of which increase the likelihood of armed conflict (Bannon and Collier, 2003; Ballentine and Nitzkschke, 2005; Collier and Hoeffler, 2005; Ross, 2001, 2003; Sachs and Warner, 2001). While analysts don't necessarily agree on the reasons why resources become linked to conflict in particular ways (and whether it is in fact a "red herring" which draws attention away from the importance of specific institutional settings; Brunnschweiler and Bulte, 2009), it is estimated that at least $40 \%$ of intrastate conflicts globally over the past 60 years have been related to natural resources (UNEP, 2009).

1 For a more extensive account of the Bougainville conflict and its links to mining related grievances, see Braithwaite et al. (2010); Filer (1990); McKenna (2016); and Regan (2003, 20I0).

2 The World Bank (20I6) broadly characterizes the PNG economy as dominated by two sectors: "the agricultural, forestry and fishing sector, which engages most of the labor force (the majority informally); and the minerals and energy extraction sector which accounts for the majority of export earnings and, from 20I5, the country's Gross Domestic Product (GDP)". 
Over the past decade, however, the academic and policy literature on natural resource conflict and CSR has made a notable shift beyond conflict analysis towards understandings of how natural resources might be extracted in ways that do not contribute to violence. New international initiatives have also been developed with the aim of encouraging corporations to adopt conflict sensitive business practices (e.g. UN Global Compact Business for Peace platform) and to "increase awareness of ethical business practices" (Business for Peace Foundation, n.d.). Moreover, numerous guidelines have emerged on issues that closely overlap with natural resource conflict such as, security, employee relations, community relations, transparency, human rights and the environment (Ballentine and Haufler, 2005, pp. I6-I7).

As PNG celebrates its 40th year of independence, the extractives industry continues to play a prominent, yet diminished role (Asian Development Bank, n.d.). While low commodity prices, unfavourable weather and disappointing mining revenues slowed economic growth in 2015, liquefied natural gas (LNG) exports and proposed new investments in the mineral sector are predicted to "boost growth in the medium term" (Asian Development Bank, n.d.). Significant recent developments include: ExxonMobil's LNG facility; a new partnership between China's Zijin and Barrick Gold at the Porgera mine in Enga Province; and debates about the potential reopening of the Panguna mine in Bougainville. It is therefore both timely and important to consider the relevance of the contemporary literature on natural resource conflict, CSR and peace building to extractive companies currently operating, or seeking to operate, in the country known as the "land of the unexpected".

This paper identifies four parallel themes in the literature and considers each with reference to examples drawn from PNG: I) the costs of conflict on business and the power of local communities; 2) tensions between the state as regulator and the state as shareholder; 3 ) the unsatisfactory performance of compensation packages and CSR projects; and 4) an emphasis on the economic dimensions of the natural resource curse in the search for new frameworks. Through a discussion of these themes, the paper calls for the development of natural resource conflict mitigation strategies that are based on a deeper understanding of the strengths and weaknesses of existing CSR measures. While CSR in PNG may have facilitated greater attention to the social impacts of their operations (Filer and Macintyre, 2006, p. 2I8), its broader peace building potential has been limited by a tendency to focus on reactive development projects, based on threats (both violent and non-violent) to corporate and state profit. The paper begins with a discussion of definitions of CSR and its evolution within the extractives industry globally. Following an examination of each of the four identified themes, the paper discusses two initiatives in PNG that seem to indicate willingness on the part of extractive companies to adopt the language of peace and reconciliation. These initiatives however, are quite different from the proposed contributions of business to peace currently emphasized in the literature. 


\section{Corporate social responsibility}

One prominent avenue for the engagement of extractive companies in responding to resource conflict has been the expansion of the theorization and practice of CSR to encompass conflict analysis and peace building. "CSR" has become recognizable shorthand for the onus on business to consider the consequences of business activity on the societies and environments in which they operate. Despite over 50 years of scholarship on CSR, there is no universally accepted definition (Dahlsrud, 2008). Moreover, various models of CSR have evolved over time, such as community relations and community development, adding further ambiguity to defining this field (Kemp, 2009, 20I0).

Attempts to address the negative impacts of business on society are not a new phenomenon. Some analysts (Cheney et al., 2007, p. 4) trace the origin of such initiatives back to the late I870s when corporate activities were beginning to be identified as having detrimental impacts on society. Corporate responses to these concerns have a similarly long history. For example, during what is known as the "progressive" era in the United States (1900-I920) industrialists were believed to have "found themselves in the awkward position of advocating a system of factory labour that, by many critics' standards, was proving to be a detriment to society" (Cheney et al., 2007, p. 4). In response, corporations began implementing employee welfare programmes designed to "curb growing dismay over the negative impact of industrialization on community and family life" (Cheney et al., 2007, p. 4). Despite these early forays into social responsibility, the core expectation of business remained to maximize profits for shareholders (Carroll, I99I, p. 39). It was not until the I970s that this view changed dramatically. At this time the establishment of a new generation of regulatory agencies in the US began to identify not just shareholders, but also the environment, employees and consumers as company "stakeholders" (Carroll, I99I, p. 39). In this way, from the I970s onwards, expectations of the responsibilities of business widened.

Within the extractives industry, CSR gained particular momentum in the I980s when an unprecedented number of extractive companies began to champion the concept (Hilson, 20I2, p. I3I). According to Hilson, only a few years earlier most extractive company chief executive officers and directors were indifferent to CSR, and some companies preferred to pay fines for noncompliance to environmental regulations than embrace the concept. In PNG, this increase has been mirrored by a dramatic rise in voluntary initiatives, codes of conduct and industry guidelines seeking to define CSR "best practice" within the extractives industry (Kepore and Imbun, 2OII). Reasons for its adoption are manifold but primarily "represent a bid to legitimize the sector after decades of environmental disasters and the trampling of indigenous rights" (Gilberthorpe and Banks, 20I2, p. I85). 
In spite of the diversity of influences of CSR, it is recognized internationally that its character as a "defensive" strategy has evolved over time. CSR in the Niger Delta for example, has advanced "into a full-blown and an expected organizational practice” (Idemudia and Ite, 2006, p. I96). This is reflected in the doubling of CSR budgets and significant contributions by extractive companies to social development infrastructure (Idemudia and Ite, 2006, p. I96). Contemporary CSR among extractive companies, therefore, is recognized as encompassing more than "just" philanthropy, sponsorships and donations (Kemp, 20IO, p. 2). In practice, CSR generally manifests as corporate commitments in the form of socio-economic development projects, security policies, community-business partnerships, social and environmental impact assessments, the adoption of discretionary codes of conduct, and can also incorporate formal agreements between states and communities. Examples from PNG include: ExxonMobil PNG Limited's half yearly environmental and social reports (ExxonMobil, 2008-20I5); Newcrest's commitment of $2.2 \%$ of revenue produced at the Lihir gold deposit on community expenditure in 2015 (Newcrest Mining Limited, 20I5, p. 49), and Barrick Gold's use of the United Nations' "Protect, Respect and Remedy" framework to guide its response to human rights abuse at the Porgera gold mine (discussed below).

\section{The costs of conflict and the power of local communities}

Adoption of CSR by the extractives industry raises questions regarding who and what is driving CSR. Calls for business to contribute to peace for example, often begin with a discussion of the costs of conflict on corporations. This is reflected in the UN Global Compact's statement "in 20I4, global economic losses due to violent conflict amounted to over US\$9.8 trillion” (UN Global Compact, n.d.). Interest in identifying the costs of conflict can be considered to stem from what is referred to in the literature as the "business case for CSR". The business case for CSR acknowledges the importance of profit to corporations and is aimed at understanding how the business community can benefit through social and environmental responsibility (Carroll and Shabana, 2010, p. 85). The logic that cost savings to business might incentivize corporate engagement is now being applied to considerations of business and conflict. As Davis and Franks (20II, p. 3) argue, an "improved understanding of the value forgone by extractive companies through conflict with local communities has the potential to translate into a strong business driver for greater attention to social and environmental issues".

The costs of violent and non-violent conflict between communities and extractive companies can be significant. According to Davis and Franks (20II, p. 3) for example, the most frequent expenses experienced by extractive companies are those caused by loss of productivity due to delay. This is reflected in PNG where it is not uncommon for landowners to "take quite dramatic action in support of their complaints and renewed claims for compensation" 
(Duncan and Duncan, 2013, p. 74). Actions that interfere with production can be both violent and peaceful. For example, in August 20I4 an attack by "armed villagers" spurred by concerns about hiring practices at the Ramu nickel mine ${ }^{3}$ injured five Chinese workers and stopped production for three days "costing millions of kina" (Callick, 20I4). ${ }^{4}$ Whereas in June 20I5, daily operations at the Lihir gold mine ${ }^{5}$ were disrupted through the placement of taboo ginger plants (gorgors) by landowners at the mine pit and other sites as a "traditional signal they want to hold discussions with the company" (Cochrane, 20I5). Community action can also result in the complete loss of a company's licence to operate, as demonstrated in the closure of the Panguna mine in Bougainville.

Yet true to business case arguments, actions that interfere with production are shown to generate corporate responsiveness. This can include for example, a higher level of interest in the social impacts of extractive projects, which was seen in PNG following the Bougainville uprising (Filer and Macintyre, 2006, p. 2I8). Perceived threats to production can also influence the calculation and distribution of formal landowner compensation payments in PNG where it is argued that, "the proper compensation recipients are those who could stop operations, and the proper amount of compensation is the lowest amount which they will accept as the price of not doing this" (Filer et al., 2000, p. 3).

The capacity to disrupt production through sabotage, violence or protest thus challenges perceptions of local communities as "powerless" in their relationships or interactions with large business enterprises" (Davis and Franks, 20II, p. 8). In fact, Imbun (2008, p. I) argues that a unique characteristic of CSR in PNG has been the "emergence of eager and sometimes restless local communities which host large mining projects and their unrelenting pressures on developers for tangible development projects" (Imbun, 2008, p. I) (such as road infrastructure, education and health services and other development needs). While this is arguably uncommon "in most developing countries with mining economies" (Imbun, 2008, p. I), a history of resistance by landowning communities in PNG has forced extractive companies to engage with their demands in order to "have a sense of social security in their operations" (Imbun, 2008, p. 4).

\section{The state as regulator and the state as shareholder}

The weight of community expectations on extractive companies operating in PNG is often attributed to poor service delivery and infrastructure development

3 "The Ramu nickel project has a planned mine life of more than 20 years and an expected production cost of around US\$10,000/tonne at full capacity, making it a truly world class asset capable of generating substantial cashflows" (Highlands Pacific Limited, n.d).

43 Papua New Guinea kina equals roughly i US dollar, as of January 2016.

5 "In the financial year ending 30 June 2015 , Lihir produced 688,714 ounces of gold. Since production commenced in I997, the site has produced more than 9 million ounces of gold" (Newcrest Mining Limited, 2016). 
by the national government in rural and remote areas (Gilberthorpe, 2007; Banks 2009, p. 53). A significant tension is that national and provincial governments in PNG are keen to exploit natural resources as a source of income, but are accused of failing to reinvest this income back into the communities that bear the negative social and environmental impacts of an extractive project (Kepore et al., 2008, p. I6). Communities such as those surrounding the Ok Tedi mine ${ }^{6}$ see the state as having "failed in its responsibilities to provide basic services and economic development initiatives" (Kepore et al., 2008, p. I6). ${ }^{7}$ This dynamic has led analysts such as Wesley-Smith (I990, pp. 3-7) to portray conflicts at extractive sites in PNG as triangular contests between "the interests of landowners on the one hand, and mining companies and the state on the other".

The state's interest in maximizing resource revenues in PNG raises concerns as to the capacity of states to regulate the extractives industry in order to protect communities from the negative impacts of resource development (WesleySmith, I990, p. 7). While the primary responsibility of states to promote responsible business practices has been affirmed in international debates concerning business and human rights (through for example, the UN "Protect, Respect and Remedy Framework" (Ruggie, 2008)), less attention has been paid to the difficulties associated with balancing the protection of minority rights with the pursuit of national economic development. Ballentine and Haufler (2005, p. 5) for instance, highlight the possibility that states might need assistance in balancing minority rights with national development. The authors argue "in an ideal world, sovereign states would be willing and able to manage peacefully their internal conflicts and husband their economic assets for the collective well-being of their citizens" (Ballentine and Haufler, 2005, p. 5). In reality however, "companies may be undercut not just by less scrupulous companies, but by host governments unconcerned or unable to address issues of corruption, criminality and conflict" (International Institute for Sustainable Development and ICUN-The World Conservation Union, 2006).

State competition with landowners may, on occasion, limit corporate capacity in relation to social and environmental responsibility. It is also important to recognize that states and resource developers are not always able to gain access to the resources they need; 97\% of land in PNG is held under customary tenure. In practice this means that while the state owns the minerals and is entitled to the returns from mineral development, it must compensate customary landholders. Thus while state control of land can at times establish extractive companies as accountable to the laws of nation states, or to local authorities, who can lack

6 Ok Tedi is an open-pit copper, gold and silver mine located in the Star Mountains of Western Province (PNG), operated by the state-owned company, Ok Tedi Mining Limited (OTML) (Ok Tedi Mining Limited, 20I6).

7 This criticism however, is not isolated to Ok Tedi. See for example, McKenna's (2016, pp. 64-78) discussion of mining in Bougainville and West Papua. This may also be a valid grievance even without a large-scale mine in the area given characterizations of PNG as a "weak" state (MacIntyre, 2008, p. I90) with poor service delivery in rural and remote areas (Gilberthorpe, 2007; Banks 2009, p. 53). 
capacity or be plagued by corruption and elite politics (Timmer, 2005), state power to "control" land is not as absolute in practice as it is in theory.

Davis and Franks (20II, p. 3) argue that, while less frequent than costs associated with disruptions to production, the greatest costs that conflict poses to extractive companies are "opportunity costs" arising from the inability to pursue future projects and/or opportunities for expansion or for sale. In PNG this has been a noted consequence of the insecurity of land access, which has seen mining companies adopt a policy of "get in and out quickly" (Duncan and Duncan, 20I3, p. 74). Manifestations of this "include flying expatriate labour in and out of the mine site rather than constructing permanent living quarters, constructing roads and bridges without long-lasting foundations, minimizing on waste disposal facilities, and no long-term skills training of indigenous labour" (Duncan and Duncan, 20I3, p. 75). Insecurity in land access, therefore, can also present costs to communities who might otherwise benefit from a more socially embedded resource project.

\section{The unsatisfactory performance of compensation packages and CSR projects}

In spite of the complexities associated with resource development in PNG, it is generally assumed that negative community perceptions of extractive projects and company-community conflict can be managed, particularly through compensation packages (Macintyre et al., 2008, p. IOI). ${ }^{8}$ This belief runs counter to the evaluation of these packages as "intrinsically unsatisfactory because they do not accord with traditional attitudes towards land ownership and use, and can never really compensate local people for the physical, social, cultural, and psychological changes associated with large scale mining" (Wesley-Smith, I990, p. 3). This experience, however, is not something that is specific to "traditional" communities. Melanesian conceptions of the environment as fusing "the social, cultural, political, economic, and environmental landscapes" (Banks, 2002, p. 4I), for example, have led some Western environmentalists to characterize Melanesians as "noble primitive ecologists" or "natural conservationists" (Macintyre and Foale, 2002). Macintyre and Foale (2002) contest the "noble primitive ecologist" characterization, claiming there is no such thing as a "natural conservationist ethic in Melanesia". Those who do make this claim, according to Macintyre and Foale, fail to acknowledge the "degrading ecological transformations brought about by indigenous inhabitants" themselves. The authors argue that, even in cases where companies are required to negotiate the terms of access to land with the customary owners, they generally do not demand stricter environmental controls (Macintyre and Foale, 2002). Rather, they demand more money. Based on this, Macintyre and Foale (2002) argue

8 See Filer (1997) for a more extensive discussion of compensation and resource development in Papua New Guinea. 
that their main concern is not the preservation of the environment per se, but the lack of utilizable resources and amenity.

The physical transformations brought about though large-scale mining, for example, are significant. The closed Panguna mine in Bougainville now represents a giant hole covering 400 hectares-land that is lost forever (Denoon, 2000 , p. I59). To construct the mine, approximately 220 hectares of tropical rainforest had to be cleared, as well as volcanic ash and weathered rock. On a daily basis, this resulted in the disposal of approximately I50,000 tonnes of rock and tailings waste, which BCL was permitted to discharge into the Kawerong River (Denoon, 2000, p. I59; Tanis, 2005, p. 452). The disposal of this waste significantly altered the Kawerong-Jaber river valleys, resulting in the loss of freshwater and fish resources for possibly several generations (AGA, I989, p. 8.5). Environmental damages also became linked to conflict when a study commissioned by the PNG Department of Minerals failed "to attribute a wide range of environmental concerns to mining activities" (BCL, 20IO-20II). 9,10

This outcome should caution against the overestimation of the positive flow-on effects of economic development or "indirect actions" by corporations to soften the adverse effects of violence in order to contribute to peace (Oetzel et al., 2007, pp. 34I-43). Fort and Schipani (2004, p. II) for example, argue that corporations are engines that produce jobs, and with them the economic and social benefits that follow from employed individuals. They identify three connections linking business and peace:

Standard ethical business practices may reduce bloodshed

Legal rules undergirding corporate governance may be reconsidered to include peace as a governance telos; and

Business could become a more important dimension of foreign policy.

Through these links, the authors identify four specific contributions business can make to peace: "fostering economic development, exercising track two diplomacy, ${ }^{11}$ adopting external evaluation principles, and nourishing a sense of community" (Fort and Schipani, 2004, p. 4). Oetzel et al. (2010) also adds risk assessment as a potential means for business to contribute to the development

9 Landowner complaints blamed on chemicals from the mine included: disappointing performance of food and cash crops; dust effects on plants; health problems and the disappearance of flying foxes (AGA, I989, p. 7.30).

10 See McKenna (20I6, Chapter 9) for a full discussion.

11 Track 2 diplomacy is defined as "unofficial dialogue and problem-solving activities aimed at building relationships and encouraging new thinking that can inform the official process" (United States Institute of Peace, 20II). 
of a more harmonious environment. Similarly, Gerson (200I, p. I03) argues that business has an important role to play in peace building as "conflict settlement requires the injection of hope born of employment and economic opportunity" and "only the private sector can provide this over the long term". The heart of Gerson's argument is that jobs and economic opportunity offer hope to the "seemingly disinherited", with new incentives to maintain stability and break the cycle of violence (200I, p. I09).

Natural resources have undoubtedly produced positive benefits for communities in PNG such as employment, business spin-offs, roads, hospitals and training. Yet Filer and Macintyre (2006, p. 2I7) argue that these benefits have largely been "off-set by a range of economic, social, political, and environmental risks and costs". A study of community perceptions at the Ok Tedi mine for example, reported "claims made by participants that, after nearly 20 years of mine operation, they had little to show in terms of socio-economic progress and development" (Kepore et al., 2008, p. I8). Moreover, while the adoption of CSR by the extractives sector in PNG "has meant safer technologies and better stakeholder engagement" (Gilberthorpe and Banks, 2012, p. I86), there is an increasing awareness that there could be limits to the value of expanding the scope of CSR to encompass conflict resolution and peace building.

Counter to normative arguments in favour of a role for business in peace, analysts have noted the unsatisfactory performance of CSR in minimizing conflict in PNG, given the lack of "evidence of any real socio-economic development at the grassroots" (Gilberthorpe and Banks, 20I2, p. I85). Explanations as to why CSR might not be the solution to the broad social and environmental problems that have plagued major extractive projects in the country vary. Gilberthorpe and Banks (2012, p. I85), for example, explain this as a consequence of the strategic business model that dominates the field of CSR in PNG and elsewhere. This model places greater emphasis on meeting “"performance standards" than on the specificities of the social contexts in which strategies are implemented" (Gilberthorpe and Banks, 20I2, p. I85). The authors argue that this approach has resulted in "ill-conceived and inappropriate development programmes that generate inequality, fragmentation, and social and economic insecurity", all of which do "little to ameliorate the social risks that were and remain a key rationale for the adoption of these social responsibilities in the first place" (2012, pp. I85-86). From another point of view, Kepore et al. (2008) highlight the lack of cohesion and coordination on the part of the recipients of socio-economic projects, which results in competing individual claims on extractive companies. Finally, McKenna (20I6, p. II) identifies limitations in the range of justice claims that CSR programmes in PNG and West Papua have been designed to redress. Drawing on an analysis of the Panguna mine, BP's Tangguh LNG project and Freeport McMoRan's Grasberg mineral deposit, McKenna (20I6, pp. II-I2) argues, "CSR has primarily been structured according to a distributive justice framework whereas armed conflicts are often also characterised by claims for cultural and political justice”. A more effective CSR therefore, might be one that balances redistribution, recognition and representation (McKenna, 20I6). 


\section{An emphasis on the economic dimensions of the natural resource curse in the search for new frameworks}

In addition to CSR, a number of new international frameworks related to natural resources have been developed with the aim of maximizing the positive potential, while mitigating the risks. Key examples include the Extractive Industry Transparency Initiative (EITI) and the implementation of the Voluntary Principles on Security and Human Rights by extractive companies. While these initiatives target specific concerns such as the elimination of corruption and human rights violations, more recent frameworks are more far-reaching, aiming to capture "the ingredients successful countries have used" (The Natural Resource Charter, 2010) to translate resource wealth into development.

Given the origins of the "natural resource curse" in economic studies in the I980s (Banks, 2005, p. I7), much of the analysis to date has been targeted at resource-abundant developing country governments and revenue management in particular. A prominent example is the Natural Resource Charter (NRC), a global initiative drafted by prominent economists including Michael Spence and Paul Collier. The NRC offers guidelines or "precepts" to manage natural resources "in a way that generates economic growth, promotes the welfare of the population, and is environmentally sustainable" (The Natural Resource Charter, 20IO, p. I). Ten of the I2 precepts outlined in the NRC are directed at the governments of resource producing states, while the remaining two target the home governments of extractive companies and extractive companies themselves. There is just one "precept" for extractive companies, which is quite broad and lacks practical detail. It simply asks companies to "follow best practice in contracting, operations and payments" (The Natural Resource Charter, 20Io, p. 2). As a result, existing recommendations largely focus on strategies that might redress or avoid the governance failures associated with natural resource wealth.

Conflicts related to natural resources however, rarely only concern revenue sharing. While contests over access to resource wealth factored into the origins of the Bougainville conflict for example, this case "involved far more complexity than natural resource revenue distribution grievances” (Regan, 20I4), including but not limited to, intergenerational tensions; the status and authority of women; and contested understandings over the environmental impacts of the Panguna mine (McKenna, 20I6). A further limitation with the overwhelming focus on economic governance by states is that less attention has been paid to leveraging the knowledge and experience of extractive companies in their own attempts to minimize the risks of violence in their areas of operation, and as potential innovators in this field.

In contrast to more familiar narratives, which link business to conflict, "more than is commonly recognized, some private sector actors have undertaken policies that seek to promote human rights and environmental health and to mitigate or avoid conflict in host communities" (Sherman, 200I, p. 3). In contrast to the business and peace literature, which tends to highlight the positive 
and indirect contributions of economic development to peace, or the focus on economic issues in the natural resource curse literature, examples found in PNG tend to target very specific issues which link extractive companies to prior conflict. It is in the handling of this complicity that extractive companies operating in PNG can be seen to have adopted the language of peace and reconciliation in their community engagement initiatives.

One such initiative evolved as a response to law and order challenges at the Porgera mine in Enga Province. In 20I0, Barrick Gold came under intense scrutiny for its operations at Porgera following the publication of a Human Rights Watch (20I0) report highlighting failures on the part of the company to recognize the risk of human rights abuses, and inadequate responses to allegations of human rights violations. In particular, Human Rights Watch uncovered a pattern of rape carried out by the mine's security force in 2009 and 20IO, as well as violence directed at "illegal miners" operating in the Special Mining Lease Area of the Porgera mine. Following its own investigations, Barrick acknowledged that at least some of these allegations were true and that a remediation process for victims would be required.

With the UN Secretary-General's Special Representative for Business and Human Rights, John Ruggie, as a special consultant on Barrick's CSR Advisory Board, the company has in part drawn on the UN's "Protect, Respect and Remedy" Framework to guide its response to these allegations. One of these initiatives, the Restoring Justice Initiative (RJI), was born out of recognition that successive national governments were not fulfilling their responsibility to provide adequate law and justice services in Porgera. This was coupled with an appreciation that without effective ways of dealing with crime and conflict, it is difficult for the company to contribute to tangible community development results. Barrick describes RJI as bringing "together government, businesses, community leaders and non-governmental organizations, who are focused on peace-building, conflict resolution, social justice and community development" (Barrick Gold Corporation, 20I4). The RJI works closely with the police and other justice agencies (including village courts and the district court) present in the Porgera valley, as well as with various community organizations, around a range of local priority issues (McKenna and Dinnen, 20I4).

Another example of corporate engagement in peace building and reconciliation in PNG is Bougainville Copper Limited's (BCL) planned participation in $\mathrm{Bel} \mathrm{Kol}$. Twenty-five years after the Panguna mine was forced to shut down, Bougainville is preparing for a deferred referendum on independence-one of the central pillars of the Bougainville Peace Agreement-to be held sometime between 2015 and 2020 (McKenna, 2015). As the territory contemplates its political future, and how it will generate the revenue needed to support meaningful autonomy or an independent state, the possibility of reopening the Panguna mine is prominent on the political agenda. One of a number of options being debated is that the mine opens again as a BCL operation, despite accusations that the company is complicit in war crimes in Bougainville (Business and Human Rights Resource Centre, n.d). 
A customary reconciliation process known as Bel Kol (translated as a cooling of the heart) between BCL, landowners, the Autonomous Bougainville Government (ABG), ex-combatants and community leaders is now under active consideration. Consideration of this began when PNG Manager for BCL met the ABG and about 40 Panguna landowner representatives. Landowners said they wanted BCL to re-establish a presence in Bougainville to begin evaluation on the extent of the environmental damage, to assess local community needs, as well as to conduct impact studies required before negotiations (Momis, 20I4, p. 5). The landowners decided that before a presence could be established, Bel Kol was essential. BCL agreed to this suggestion and it was anticipated to occur in 20I4, but has since been delayed (McKenna, 2016).

\section{Conclusion}

The contemporary literature on natural resource conflict, CSR and peace building is of relevance to the extractives industry in PNG. Extractive companies operating in the country are shown to respond to conflict, particularly when it interferes with production. The dominant strategy deployed by extractive companies to counter these threats has been CSR and compensation packages. These strategies however, are not believed to have been effective in minimizing violent conflict at extractive sites in PNG, although more research needs to be conducted into why this is the case.

The economic dimensions of the natural resource curse are also identifiable in PNG, but conflicts related to natural resources do not exclusively concern revenue distribution and economic inequality. Instead, "resource conflicts" encompass a broader range of issues that might be considered "cultural", "political" and environmental". It is important therefore, that the development of new strategies aimed at exploiting natural resources peacefully engages with a full range of community grievances that link extractive sites to conflict.

One underexplored source of learning in this regard is the experiences of extractive companies in their own attempts to manage company-community conflict in their areas of operation. In PNG, these initiatives are quite different from the positive flow-on effects of economic development emphasized in the business and peace literature. The RJI and Bel Kol examples, in contrast, target very specific areas that have previously linked their business practices to conflict. Future research might explore, for example, the peace building potential of access to remedy initiatives under the rubric of the UN Protect, Respect and Remedy Framework, or the strengths and weaknesses of customary reconciliation processes to rectify past harms. 


\section{References}

Applied Geology Associates Ltd (AGA) (1989). Environmental, Socio-Economic and Public Health Review of Bougainville Copper Mine, Panguna. New Zealand: Applied Geology Associates Ltd.

Asian Development Bank (n.d). Papua New Guinea: Economy. Retrieved from: http://www. adb.org/countries/papua-new-guinea/economy

Ballentine, K., \& Haufler, V. (2005). Enabling economies of peace: Public policy for conflict-sensitive business. Retrieved from: https://www.unglobalcompact.org/docs/news_ events/8.I/enabling_econ.pdf

Ballentine, K., \& Nitzschke, H. (2005). The Political Economy of Civil War and Conflict Transformation. Berlin: Berghof Research Center for Constructive Conflict Management. Retrieved from: http:// www.researchgate.net/profile/Heiko_Nitzschke/publication/2556oI4I7_The_Political_ Economy_of_Civil_War_and_Conflict_Transformation/links/53fffd96ocf2c9c3309df3oe .pdf

Banks, G. (2002). Mining and the environment in Melanesia: Contemporary debates reviewed. The Contemporary Pacific, I4(I), 39-67.

Banks, G. (2005). Linking resources and conflict the Melanesian way. Pacific Economic Bulletin, 20(I). Retrieved from: http://peb.anu.edu.au/pdf/PEB20-IBanks.pdf

Banks, G. (2008). Understanding "resource" conflicts in Papua New Guinea. Asia Pacific Viewpoint, 49(I). doi: I0.IIII/j.I467-8373.2008.00358.x

Banks, G. (2009). Activities of TNCs in extractive industries in Asia and the Pacific: implications for development. Transnational Corporations, I8(II). Retrieved from: http://unctad .org/en/docs/diaeiia20097a2_en.pdf

Bannon, I., \& Collier, P. (Eds.). (2003). Natural Resources and Violent Conflict: Options and Actions. Washington: The World Bank.

Barrick Gold Corporation (20I4). Neighborhood watch: How the restoring justice initiative addresses law and order challenges in the Porgera district. Retrieved from: http:// barrickbeyondborders.com/people/20I4/II/neighborhood-watch-how-the-restoringjustice-initiative-addresses-law-and-order-challenges-in-the-porgera-district/

Bougainville Copper Limited (20I0-20II). Chronology of events. Retrieved from: http://bcl .nlawebdesigns.com/bougainville/chronology-of-events.html

Braithwaite, J., Charlesworth, H., Reddy, P. \& Dunn, L. (2010) Reconciliation and Architectures of Commitment: Sequencing Peace in Bougainville. Canberra: ANU E Press,

Brunnschweiler, C.N., \& Bulte, E.H. (2009). Natural resources and violent conflict: resource abundance, dependence, and the onset of civil wars. Oxford Economic Papers, 6I(4). doi: I0.1093/oep/gppo24

Business \& Human Rights Resource Centre (n.d.). Rio Tinto lawsuit (re Papua New Guinea). Retrieved from: http://business-humanrights.org/en/rio-tinto-lawsuit-re-papua-newguinea\#c9304

Business for Peace Foundation (n.d.). About us. Retrieved from: http://businessforpeace. no/about-us

Callick, R. (20I4). China's Ramu nickel mine in PNG attacked by armed villagers. The Australian. Retrieved from: http://www.theaustralian.com.au/business/mining-energy/chinas-ramunickel-mine-in-png-attacked-by-armed-villagers/story-e6frg9df-I227015819352 
Carroll, A.B., \& Shabana, K.M. (2010).The business case for corporate social responsibility: A review of concepts, research and practice. International Journal of Management Reviews, I2(I). doi: т0.IIII/j.I468-2370.2009.00275.x

Carroll, A.B. (I99I). The pyramid of corporate social responsibility: Toward the moral management of organizational stakeholders. Business Horizons, July-Aug. doi: Io.IoI6/ 0007-68I3(9I)90005-G

Cheney, G., Roper, J., \& May, S.K. (2007). Overview. In S.K. May, G. Cheney \& J. Roper (Eds.), The Debate over Corporate Social Responsibility, 3-I4. Oxford: Oxford University Press.

Cochrane, L. (20I5, June 8). Police sent to reopen PNG gold mine after locals use taboo plant to demand talks with Newcrest. $A B C$ News. Retrieved from: http://www.abc.net. $\mathrm{au} /$ news/2015-06-08/police-sent-to-png-gold-mine-after-two-day-shutdown/6530424

Collier, P., \& Hoeffler, A. (2005). Resource rents, governance, and conflict. The Journal of Conflict Resolution, 49(4). doi: I0.1177/0022002705277551

Collier, P. (2000). Economic Causes of Civil Conflict and their Implications for Policy. Washington: World Bank.

Dahlsrud, A. (2008). How corporate social responsibility is defined: An analysis of 37 definitions. Corporate Social Responsibility and Environmental Management, I5. doi: I0.I002/ CSr.I32

Davis, R., \& Franks, D.M. (20II). The costs of conflict with local communities in the extractive industry. Proceedings of the First International Seminar on Social Responsibility in Mining. Chile: Santiago. Retrieved from: https://www.csrm.uq.edu.au/Portals/o/iIsrm_capo6_ p88.pdf

Denoon, D. (2000). Getting Under the Skin: The Bougainville Copper Agreement and the Creation of the Panguna Mine. Carlton: Melbourne University Press.

ExxonMobil (2008-20I5). Environmental and social reports. Retrieved from: http://pnglng. com/commitment/plans-and-reporting/environmental-and-social-reports.html

Dinnen, S., Mcleod, A., \& Peake, G. (2006). Police-building in weak states: Australian approaches in Papua New Guinea and Solomon Islands. Civil Wars, 8(2). doi: I0.1080/13698240600877221

Duncan, R., \& Duncan, R. (2013). Improving security of access to customary-owned land in Melanesia: Mining in Papua New Guinea. In P. Larmour (Ed.). The Governance of Common Property in the Pacific Region, 73-88. Canberra: ANU E Press. Retrieved from: http:// press.anu.edu.au/titles/the-governance-of-common-property-in-the-pacific-region/ pdf-download-4/

Filer, C. (I990). The Bougainville rebellion, the mining industry and the process of social disintegration in Papuan New Guinea. In R.J. May \& M. Spriggs (Eds.), The Bougainville Crisis. Bathurst: Crawford House Press.

Filer, C. (I997). Compensation, rent and power in Papua New Guinea. In S. Toft (Ed.), Compensation for Resource Development in Papua New Guinea. Canberra: National Centre for Development Studies and Resource Management in Asia-Pacific Project (Australian National University); Boroko: Law Reform Commission (Papua New Guinea).

Filer, C., \& Macintyre, M. (2006). Grass roots and deep holes: Community responses to mining in Melanesia. The Contemporary Pacific, I8(2). doi: I0.1353/cp. 2006.00I2

Filer, C., Jackson, R.T., \& Henton, D. (2000). Landowner Compensation in Papua New Guinea's Mining and Petroleum Sectors. Port Moresby: PNG chamber of Mines and Petroleum.

Fort, T.L., \& Schipani, C.A. (2004). The Role of Business in Fostering Peaceful Societies. Cambridge: Cambridge University Press.

Gerson, A. (200I). Peace building: The private sector's role. The American Journal of International Law, 95(I). doi: $10.2307 / 2642040$

Gilberthorpe, E. (2007). Fasu solidarity: A case study of kin networks, land tenure, and oil extraction in Kutubu, Papua New Guinea. American Anthropologist, Io9(I). doi: I0.1525/ aa.2007.IO9.I.IOI 
Gilberthorpe, E., \& Banks, G. (2012). Development on whose terms? CSR discourse and social realities in Papua New Guinea's extractive industries sector. Resources Policy, 37(2). doi: го.Іол6/j.resourpol.2011.09.005

Highlands Pacific (n.d). Ramu nickel. Retrieved from: http://www.highlandspacific.com/ current-projects/ramu-nickel

Hilson, G. (20I2). Corporate Social Responsibility in the extractive industries: Experiences from developing countries. Resources Policy, 37(2). doi: I0.10I6/j.resourpol.2012.01.002

Human Rights Watch (2010). Gold's costly dividend: Human rights impacts of Papua New Guinea's Porgera gold mine. Retrieved from: https://www.hrw.org/sites/default/files/ reports/pngo2iıwebwcover.pdf

Idemudia, U., \& Ite, U.E. (2006). Corporate-community relations in Nigeria's oil industry: challenges and imperatives. Corporate Social Responsibility and Environmental Management, I3(4). doi: IO.IOO2/csr.IOI

Imbun, B.Y. (2007). Cannot manage without the, "significant other": Mining, corporate social responsibility and local communities in Papua New Guinea. Journal of Business Ethics, 73(2), I77-192.

Imbun, B.Y. (2008). Mining, corporate social responsibility and pluralism in Papua New Guinea. Retrieved from: https://www.researchgate.net/publication/239919222_MINING_ CORPORATE_SOCIAL_RESPONSIBILITY_AND_PLURALISM_IN_PAPUA_NEW_ GUINEA

International Institute for Sustainable Development \& ICUN - The World Conservation Union (2006). Promoting conflict-sensitive business: Fostering responsible business in fragile states. Retrieved from: http://www.iisd.org/pdf/2005/tas_objective_5.pdf

Kemp, D. (2009). Mining and community development: Problems and possibilities of locallevel practice. Community Development Journal, 45(2), I98-218.

Kemp, D. (20I0). Community relations in the global mining industry: Exploring the internal dimensions of externally oriented work. Corporate Social Responsibility and Environmental Management, I7, I-I4.

Kepore, K., Goddard, R., \& Higgins, C. (2008). The rhetoric and reality of corporate social responsibility: A case study in the mining industry in Papua New Guinea. Retrieved from: http://albanyrecreation.ac.nz/massey/fms/Colleges/College\%2oof\%2oBusiness / Communication\%20and\%20Journalism/ANZCA\%202008/Refereed\%20Papers / Kepore_Goddard_Higgins_ANZCAo8.pdf

Kepore, K.P., \& Imbun, B.Y. (2OII). Mining and stakeholder engagement discourse in a Papua New Guinea mine. Corporate Social Responsibility and Environmental Management, $8(4), 220-233$.

Kirsch, S. (2007). Indigenous movements and the risks of counterglobalization: Tracking the campaign against Papua New Guinea's Ok Tedi mine. American Ethnologist, 34(2), 303-32I.

Macintyre, M., \& Foale, S. (2002). Politicised ecology: Local responses to mining in Papua New Guinea. Resource Management in Asia-Pacific, Working Paper No.33. Retrieved from: http://www.crawford.anu.edu.au/rmap/pdf/Wpapers/rmap_wp33.pdf

Macintyre, M., Mee, W., \& Solomon, F. (2008). Evaluating social performance in the context of an "audit culture": a pilot social review of a gold mine in Papua New Guinea. Corporate Social Responsibility and Environmental Management, I5(2), I00-IIO.

McKenna, K. (20I5). Mining and reconciliation: Negotiating the future of the Panguna mine in Bougainville. SSGM In Brief, 35. Retrieved from: http://ips.cap. anu.edu.au/sites/ default/files/SSGM\%20IB\%2020I5-35\%20McKenna_o.pdf

McKenna, K. (20I6). Corporate Social Responsibility and Natural Resource Conflict. Abingdon, UK: Routledge. 
McKenna, K., \& Dinnen, S. (20I4). Operationalising the United Nations' "protect, respect and remedy" framework at the Porgera gold mine, Papua New Guinea. SSGM In Brief. Retrieved from: https://www.academia.edu/9802569/Operationalising_the_United_ Nations_Protect_Respect_and_Remedy_Framework_at_the_Porgera_Gold_Mine_ Papua_New_Guinea

Momis, J. (20I4). Letter to members of the board of Jubilee Australia re. Voice of Bougainville report.

Newcrest Mining Limited (20I6). Lihir, PNG. Retrieved from: http://www.newcrest.com.au/ our-business/operations/lihir

Oetzel, J., Getz, K.A., \& Ladek, S. (2007). The role of multinational enterprises in responding to violent conflict: A conceptual model and framework for research. American Business Law Journal, 44(2). doi: I0.IIII/j.I744-I7I4.2007.00039.x

Oetzel, J., Westermann-Behaylo, M., Koerber, C., Fort., T.L., \& Rivera, J. (20I0). Business and peace: Sketching the terrain. Journal of Business Ethics, 89, 35I-373.

Ok Tedi Mining Limited (20I6). Ok Tedi Mining. Retrieved from: http://www.oktedi.com

rait man (20I4). Why bel kol with BCL is not well received by local people of Bougainville. ACT NOW! Retrieved from: http://actnowpng.org/blog/why-bel-kol-bcl-notwell-received-local-people-bougainville

Regan, A. (2003). The Bougainville conflict: Political and economic agendas. In K. Ballentine \& J. Sherman (Eds.). The Political Economy of Armed Conflict: Beyond Greed and Grievance. Boulder, CO: Lynne Rienner.

Regan, A.J. (20I0). Light Intervention: Lessons from Bougainville. Washington: US Institute of Peace Press.

Regan, A. (2013). Bougainville: Conflict deferred? In E. Aspinall, R. Jeffrey \& A.J. Regan (Eds.), Diminishing Conflicts in Asia and the Pacific. Abingdon \& New York: Routledge.

Regan, A.J. (20I4). Bougainville: Large-scale mining and risks of conflict recurrence. Security Challenges, IO(2), 7I-96.

Ross, M. (200I). Does oil hinder democracy? World Politics, 53, 325-36r.

Ross, M. (2003). The natural resource curse: How wealth can make you poor. In I. Bannon \& P. Collier (Eds.), Natural Resources and Violent Conflict: Options and Actions. Washington: World Bank.

Ruggie, J. (2008). Protect, respect and remedy: A framework for business and human rights. Innovations, 3(2), I89-212.

Sachs, J.D., \& Warner, A.M. (200I). Natural resources and economic development: The curse of natural resources. European Economic Review, 45, 827-838.

Sherman, J. (200I). Private sector actors in zones of conflict: Research challenges and policy responses. International Peace Academy Workshop Report. Retrieved from: http://www. fafoarkiv.no/nsp/ipa-report.pdf

Tanis, J. (2005). Nagovisi villages as a window on Bougainville in I988. In A.J Regan \& H.M Griffin (Eds.), Bougainville Before the Conflict. Canberra: Pandanus Books.

The Natural Resource Charter (20I0). Natural resource charter. Retrieved from: http:// naturalresourcecharter.org/sites/default/files/NRC\%20Eng_2oIr.pdf

The World Bank (20I6). Overview. Retrieved from: http://www.worldbank.org/en/country/ png/overview\#I

Timmer, J. (2005). Decentralisation and elite politics in Papua. State, Society and Governance in Melanesia Discussion Paper, 6. Retrieved from: https://digitalcollections.anu.edu.au/ handle/I885/IOI37

UN Global Compact (n.d.). Peace. Retrieved from: https://www.unglobalcompact.org/ what-is-gc/our-work/governance/peace 
United Nations Development Program (UNDP) (2012). About Papua New Guinea. Retrieved from: http://www.pg.undp. org/content/papua_new_guinea/en/home/countryinfo.html

United Nations Environment Programme (2009). From conflict to peacebuilding: The role of natural resources and the environment. Retrieved from: http://www.unep. org/pdf/ pcdmb_policy_or.pdf

United States Institute of Peace (20II). Glossary of terms for conflict management and peacebuilding. Retrieved from: http://glossary.usip. org/resource/tracks-diplomacy

Wesley-Smith, T. (I990). The politics of access: mining companies, the state, and landowners in Papua New Guinea. Political Science, 42(2), I-I9. 